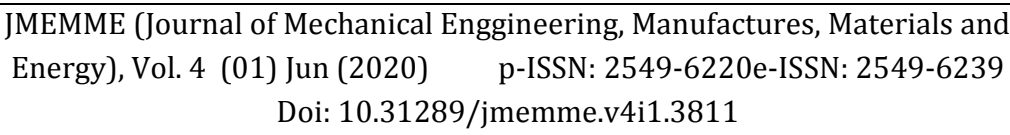

JMEMME (Journal of Mechanical Engineering, Manufactures, Materials and Energy)

\title{
Simulasi Pembebanan Pada Shackle Menggunakan Perangkat Lunak Ansys APDL 15.0
}

\section{Simulations of Loading in Shackle Using Ansys APDL 15.0 Software}

\author{
Al'Azryan A.M. Harahap \\ Program Studi Teknik Mesin, Universitas Medan Area \\ Submitted: 01-06-2020 ; Accepted: 20-06-2020 ; Published: 30-06-2020 \\ *Corresponding author: alazriyanharahap@gmail.com
}

\begin{abstract}
Abstrak
Berbagai jenis teknologi rekayasa dan simulasi telah banyak dikembangkan yang bertujuan untuk memudahkan pekerjaan manusia. Shackle adalah alat yang dipergunakan untuk mengangkat serta memindahkan suatu benda dari satu tempat ke tempat lainnya. Pada penelitian ini, akan dihitung distribusi tegangan yang terjadi pada shackle pada kondisi pengangkatan tangki minyak kapasitas 6 ton. Perhitungan dengan menggunakan prinsip metode elemen hingga dengan bantuan software Ansys APDL 15.0. Tujuan penelitian ini ialah: (1) mendesain bentuk shackle dan kondisi pembebanan, (2) simulasi distribusi tegangan pada pin dan struktur shackle, dan (3) analisa kegagalan bahan dengan menggunakan metode Tresca dan Energi Distorsi. Beban input berasal dari berat tangki yang akan digunakan dan berat bahan bakar yang disimpan dalam tangki. Metode analisis menggunakan MEH dengan jenis analisa structural den jenis elemen Beam 3Node 189. Berdasarkan hasil simulasi MEH, tegangan maksimum yang terjadi pada pin ialah 29,864 MPa dan defleksi maksimum ialah 0,0026 mm. Tegangan maksimum pada shackle ialah 76,02 MPa dan defleksi maksimum ialah 0,1881 mm. Berdasarkan teori Tresca dan Energi Distorsi, diperolah bahwa tegangan yang terjadi masih jahu dari kriteria kegagalan struktur. Demikian juga dengan defleksi yang terjadi sangat kecil sehingga shackle aman digunakan
\end{abstract}

Kata Kunci: Shackle, Simulasi MEH, Analisa Kegagalan

\begin{abstract}
Various types of engineering and simulation technology have been developed that aim to facilitate human work. Shackle is a device used to lift and move an object from one place to another. In this research, we will calculate the stress distribution that occurs in the shackle under the lifting conditions of the 6 ton oil tank. Calculations using the principle of the finite element method with the help of Ansys APDL 15.0 software. The objectives of this study are: (1) designing the shape of the shackle and loading conditions, (2) simulating the stress distribution on the pin and shackle structure, and (3) analyzing the failure of the material using the Tresca and Distortion Energy methods. The input load comes from the weight of the tank to be used and the weight of the fuel stored in the tank. The method of analysis uses MEH with structural analysis type and Beam 3 Node 189 type elements. Based on the results of the MEH simulation, the maximum stress that occurs at the pin is $29.864 \mathrm{MPa}$ and the maximum deflection is $0.0026 \mathrm{~mm}$. The maximum stress on the shackle is 76.02 MPa and the maximum deflection is $0.1881 \mathrm{~mm}$. Based on Tresca's theory and Distortion Energy, it was found that the stress that occurs is still long from the criteria of structural failure. Likewise, the deflection that occurs is very small so that the shackle is safe to use.
\end{abstract}

Keywords: Shackle, MEH Simulation, Failure Analysis 
JMEMME (Journal of Mechanical Enggineering, Manufactures, Materials and Energy), 4 (o1) (2020): 74-84

How to Cite: Harahap, A.A.M., 2020, Simulasi Pembebanan Pada Shackle Menggunakan Perangkat Lunak Ansys APDL 15.0, JMEMME (Journal of Mechanical Enggineering, Manufactures, Materials and Energy), 4(01): 74-84 


\section{PENDAHULUAN}

Perkembangan teknologi sekarang telah banyak menghasilkan kreasi yang bertujuan untuk memudahkan pekerjaan manusia, serta dapat meningkatkan kualitas dan kuantitas produksi. Shackle adalah alat bantu yang digunakan pada proses pengangkatan suatu benda atau konstruksi di pabrik/industri, konstruksi bangunan, dll. Shackle diperlukan untuk mengangkat serta memindahkan suatu benda dari satu tempat ke tempat lainnya. Shackle merupakan gabungan mekanisme pengangkat secara terpisah dengan rangka untuk mengangkat atau sekaligus mengangkat dan memindahkan muatan yang dapat digantungkan secara bebas atau diikatkan pada shackle [1].

Shackle memiliki komponen utama yang disebut dengan hook (kait) di mana komponen ini berfungsi sebagai pengait yang menghubungkan beban pada crane. Shackle terdiri dari alat bantu pengait antara crane dan skid, dan sling, yaitu tali kawat atau kabel yang digunakan untuk mengikatkan shackle pada hook yang terdapat pada crane. Dalam aplikasinya, alat yang akan diangkat pada umumnya menggunakan objek solid kupingan (lifting lug) dengan bagian tengahnya terdapat lubang berbentuk lingkaran. Alat ini diikatkan pada lifting lug sehingga hook dapat dicantolkan padanya [2].

Pada penelitian, distribusi beban yang terjadi pada shackle akan dihitung dengna menggunakan metode elemen hingga. Proses ini dibantu dengan menggunakan software Ansys APDL 15.0. Beberapa penelitian sebelumnya telah menggunakan software ini untuk keperluan simulasi pembebanan pada beberapa benda. Kekuatan batang penahan rem belakang sepeda motor telah diteliti dan hasilnya diperlukan struktur penguat tambahan pada ikatan batang tersebut dengan rumah rem [3]. Analisa kekuatan rangka struktur mesin pengering bawang dengan software Ansys dan hasilnya kekuatan struktur dinyatakan aman jika dilihat dari perpindahan nodal yang terjadi serta berdasarkan kreiteria kegagalan struktur [4] [5].

Beban dapat diklasifikasikan menjadi beberapa jenis yaitu beban operasional, beban dari alam atau lingkungan dan beban sustain (beban dari material itu sendiri). Beban operasional adalah beban yang timbul akibat adanya gerakan dan operasi dari material tersebut, seperti beban yang timbul akibat putaran yang akan menghasilkan torsi dan lain-lain. Beban dari alam/lingkungan adalah beban yang diterima oleh suatu material akibat kondisi alam/lingkungan sekitar, seperti beban yang diberikan akibat angin, gempa dan lainnya [6].

Setiap material memiliki berat, dimana berat merupakan sifat fisik dari material yang dipengaruhi oleh massa benda. Sifat fisik dari material ini akan menimbulkan suatu gaya atau berat dari material tersebut apabila dipengaruhi oleh gaya grafitasi [7]. Pada penelitian ini perhitungan pembebanan yang terjadi pada shackle bertujuan untuk mengetahui gaya yang terjadi pada shackle saat mengangkat tangki destilasi Pertamina. Ukuran dimensi tangki destilasi Pertamina adalah tinggi 2,1 meter dan diameter alas 1,51 m. Untuk 
objek yang cukup besar dan sulit untuk diukur langsung, maka dapat digunakan dengan pendekatan terhadap densitas bahan dengan menggunakan persamaan (1).

$$
\mathrm{m}=\rho \cdot \mathrm{V}
$$

dimana m ialah massa objek, $\rho$ ialah densitas bahan, dan $\mathrm{V}$ ialah volume objek.

Untuk menganalisa suatu struktur harus memperhatikan tegangan, regangan dan deformasi yang terjadi. Menurut Shigley's, persamaan tegangan didefinisikan sebagai gaya persatuan luas dan yang dituliskan seperti pada persamaan 2 .

$$
\sigma=\mathrm{F} / \mathrm{A}
$$

Dimana, $\sigma$ ialah tegangan $(\mathrm{N} / \mathrm{m} 2), \mathrm{F}$ ialah gaya $(\mathrm{N})$ dan $\mathrm{A}$ ialah luas satuan permukaan yang mengalami pembebanan (m2).

Regangan $(\varepsilon)$ adalah perbandingan deformasi total terhadap panjang mulamula suatu struktur. Definisi regangan tersebut dituliskan dalam persamaan 3 .

$$
\varepsilon=\delta / L_{0}
$$

Dimana, $\varepsilon$ ialah regangan, $\delta$ ialah pertambahan panjang (defleksi), dan L0 ialah panjang benda mula-mula.

Sedangkan untuk elastisitas (E) didefinisikan berdasarkan hukum Hooke yang memenuhi hubungan persamaan (4). Berdasarkan hukum Hooke tersebut dijelaskan bahwa transisi dari elatisitas menuju plastis dinamakan kekuatan luluh (yield strength) [8]. jika diberikan penambahan beban diatas batas kekuatan luluhnya maka struktur tersebut akan bersifat patah

$$
\sigma=\varepsilon . \mathrm{E}
$$

Secara mendasar kegagalan (failure) dari suatu struktur dinyatakan bila struktur tidak dapat berfugsi lagi dengan baik untuk menerima pembebanan [4]. Prosedur untuk pemeriksaan terperinci dan analisis bagian shackle yang rusak adalah sebagai berikut: inspeksi visual bagian tersebut, fraktografi menggunakan SEM, analisis kimia bahan, metalografi optik, uji kekerasan mikro Vickers, dan non logam uji inklusi.

Terdapat 2 jenis kriteria kegagalan akibat pembebanan statik, yaitu: (1) Deformasi Plastis terjadi jika material dari struktur sudah mengalami deformasi plastis karena sudah melewati batas tegangan atau regangan luluh (yield point) material, dan (2) Patah atau Rusak terjadi bila material dari struktur tersebut sudah patah ataumelewati batas tegangan maksimum yang diizinkan material [8].

Teori tegangan geser maksimum memprediksi bahwa peluluhan dimulai ketika tegangan geser yang terjadi melebihi tegangan izin maksimum dari sebuah elemen. Teori tegangan geser maksimum juga disebut sebagai teori Tresca atau teori Guest. Tegangan geser maksimum yang memenuhi persamaan 5 [8].

$$
\mathrm{V}_{\mathrm{Nax}}=(\sigma 1-\sigma 3) / 2 \geq \mathrm{Sy} / 2
$$


Kegagalan terjadi apabila $(\sigma 1-\sigma 3$ J/2lebih besar dari Sy/2. Sy merupakan yield strength, yakni nilai kekalahan dari material bahan.

Energi distorsi terjadi jika energi regangan distorsi persatuan volume mencapai atau melebihi energi regangan distorsi persatuan volume untuk menghasilkan tegangan dari elemen yang sama. Teori energi distorsi berkaitan dengan teori Von Misess Stress. Teori energi distorsi ini bisa membuktikan apakah hasil tegangan eqivalen simulasi sesuai dengan hasil perhitungan teori energi distorsi. Teori energi distorsi dituliskan dalam bentuk persamaan 6 [8].

$\mathrm{a}^{\prime} \geq \mathrm{Sy}$

$[((\sigma 1-\sigma 2) 2+(\sigma 2-\sigma 3) 2+(\sigma 3-\sigma 1) 2) / 2] 1 / 2$ $\geq$ Sy

Kegagalan terjadi apabila [(a1-a2)2+(a2-a3)2+(a3-a1)2] 1/2 lebih besar dari Sy. Sy merupakan yield strength, yakni nilai kekalahan dari material bahan.

ANSYS adalah suatu perangkat lunak komputer khusus Engineering yang mampu menyelesaikan persoalanpersoalan elemen hingga dari pemodelan hingga analisis [9]. Ansys ini digunakan untuk mensimulasikan semua disiplin ilmu fisika baik statis maupun dinamis, analisis struktural (keduaduanya linier dan nonliner), perpindahan panas, dinamika fluida, dan elektromagnetik untuk para engineer. ANSYS dapat mengimpor data CAD dan juga memungkinkan untuk membangun geometri dengan kemampuan yang "preprocessing". Demikian pula dalam preprocessor yang sama, elemen hingga model (jaring alias) yang diperlukan untuk perhitungan dihasilkan. Setelah mendefinisikan beban dan melakukan analisis, hasil dapat dilihat sebagai numerik dan grafis. Hasil yang diperoleh dari ANSYS ini berupa pendekatan dengan menggunakan analisa numerik. Ketelitiannya sangat bergantung pada cara kita memecah model tersebut dan menggabungkannya. Secara umum, suatu solusi elemen hingga dapat dipecahkan dengan mengikuti 3 tahapan. Tahapan Ini merupakan panduan umum yang dapat digunakan untuk menghitung analisis elemen hingga.

Tujuan dalam penelitian ini adalah: (1) melakukan desain bentuk shackle dengan bantuan software Ansys untuk keperluan simulasi numerik, mendapatkan distribusi tegangan dan perpindahan nodal pada shackle akibat berat tangki yang diteliti, dan (3) analisa kegagalan shackle dengan metode Maximum shear stress dan Distortion energy.

\section{METODE}

Penelitian ini dilaksanakan di Laboratorium Proses Produksi, Program Studi Teknik Mesin, Fakultas Teknik, Universitas Medan Area, jalan Kolam No.1 Medan Estate selama 3 bulan. Perangkat keras (hardware) yang dipergunakan dalam penelitian ini Laptop dengan spesifikasi sebagai berikut: TOSHIBA SATELITE, Type Processor: Intel(R)Core(TM) i5-4200M CPU @2,50GHz, Memory: 4.00GB, dan Display Mode: 1366x768(64bit)(60Hz). 
Perangkat lunak (software) yang digunakan ialah ANSYS APDL 15.0.

Dimensi objek diukur dengan menggunakan alat ukur jangka sorong jenis Vernier Caliper dan meteran gulung 2 m. Berat objek diukur dengan menggunakan pendekatan persamaan (1).

Prosedur simulasi software Ansys APDL 15.0 ialah: (1) proses preferensi merupakan langkah pendahuluan untuk menentukan model analisa terhadap kondisi meterial yang ada, (2) penentuan element type dengan jenis yang digunakan adalah element type solid Quad 4node 182, (3) menentukan real constant, (4) pendefinisian material properties, (5) pemberian tumpuan dan beban, (6) simulasi numerik (Solve Current LS), dan (7) pengamatan hasil (Postprocessor).

\section{HASIL \& PEMBAHASAN}

Perhitungan pembebanan yang terjadi pada Shackle bertujuan untuk mengetahui gaya yang terjadi pada tumpuan. Dari hasil pengambilan data diketahui bahwa massa tangki ialah 916,72 kg dan massa minyak yang dimuat dalam tangki adalah $5000 \mathrm{~kg}$. Dengan demikian massa total objek yang akan dianalisa ialah $5916,72 \mathrm{~kg}$ atau $58.043 \mathrm{~N}$. Tangki ditopang oleh 2 buah lifting lug, sehingga gaya objek pada masing-masing lug ialah setengah dari total gaya tersebut, yaitu 29.021,5 N. Diasumsikan terjadi bebab terbagi merata pada lug, maka gaya pada masing-masing lug dibagi lagi dengan jumlah node sebanyak 26 node, sehingga masing- masing node akan mengalami gaya sebesar 1116,21 N.
Proses permodelan adalah proses membuat element (benda) yang akan diteliti. Dalam permodelan penelitian ini terdapat 2 model objek element yang akan di uji, yaitu pin, dan shackle itu sendiri. Hasil pemodelan pada pin diperlihatkan pada gambar 1. Hasil simulasi pada pin terhadap perpindahan nodal dan tegangan akibat beban yang diberikan diperliatkan pada gambar 2 dan 3.

Berdasarkan hasil simulasi terlihat bahwa daerah kritis pada pin berdasarkan perpindahan nodal terjadi pada daerah pertengahan pin, yaitu pada bagian yang kontak lansung dengan lifting lug. Tetapi nilai perpindahan yang dihasilkan masih sangat kecil sekali, yaitu maksimum 0,002696 mm. Dengan demikian jika ditinjau dari segi perpindahan nodal, maka konstruksi pin masih dalam kategori aman dipergunakan.

Keamanan konstruksi pin jika ditinjau dari hasil simulasi tegangan harus diperiksa dengan menggunakan metode teori kegagalan yang telah dijelaskan sebelumnya. Berdasarkan hasil simulasi, gaya reaksi pada pin akibat gaya berat tangki diperlihatkan pada gambar 4 .

Gaya-gaya reaksi tersebut akan digunakan sebagai beban ekternal di kaki-kaki shackle. Hasil pemodelan shackle diperlihatkan pada gambar 5 . Hasil simulasi perpindahan nodal dan distribusi tegangan pada shackle diperlihatkan pada gambar 6 dan 7 . 
Harahap, A.A.M., Simulasi Pembebanan Pada Shackle Menggunakan ....

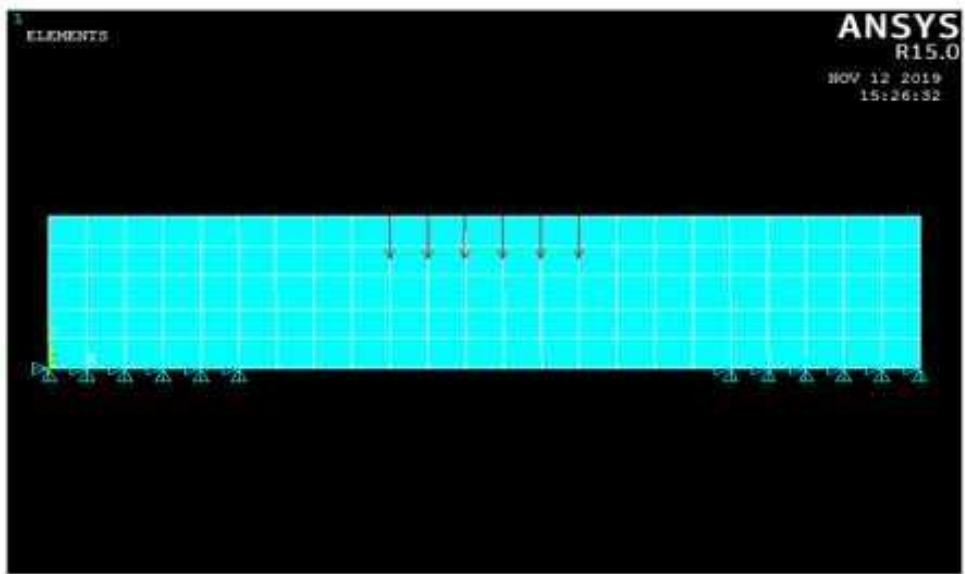

Gambar 1. Pemodelan objek, tumpuan, dan beban pada pin

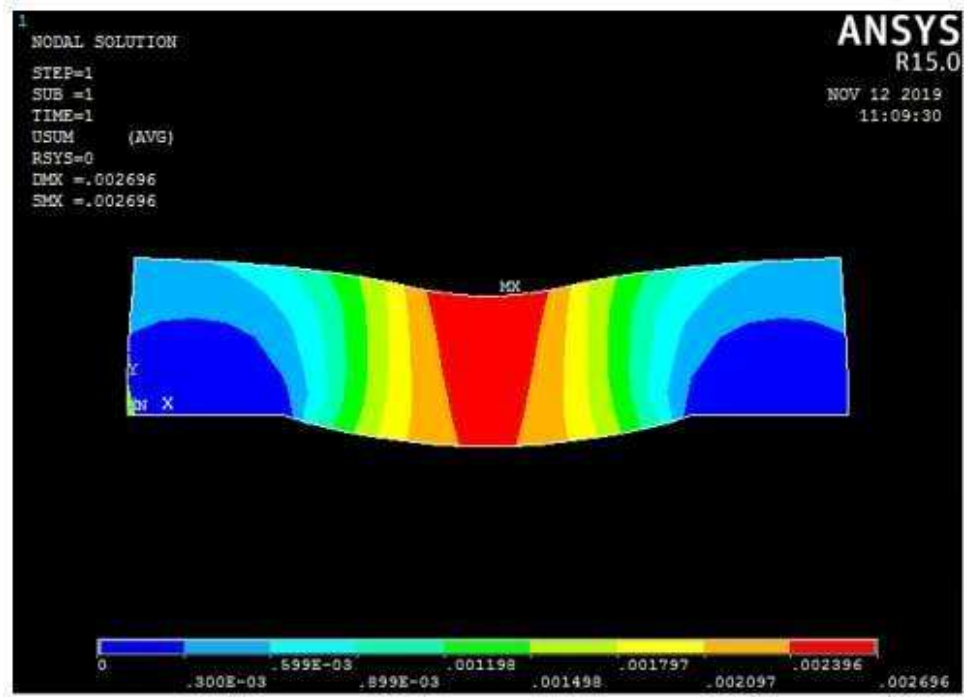

Gambar 2. Hasil simulasi perpindahan nodal pada pin

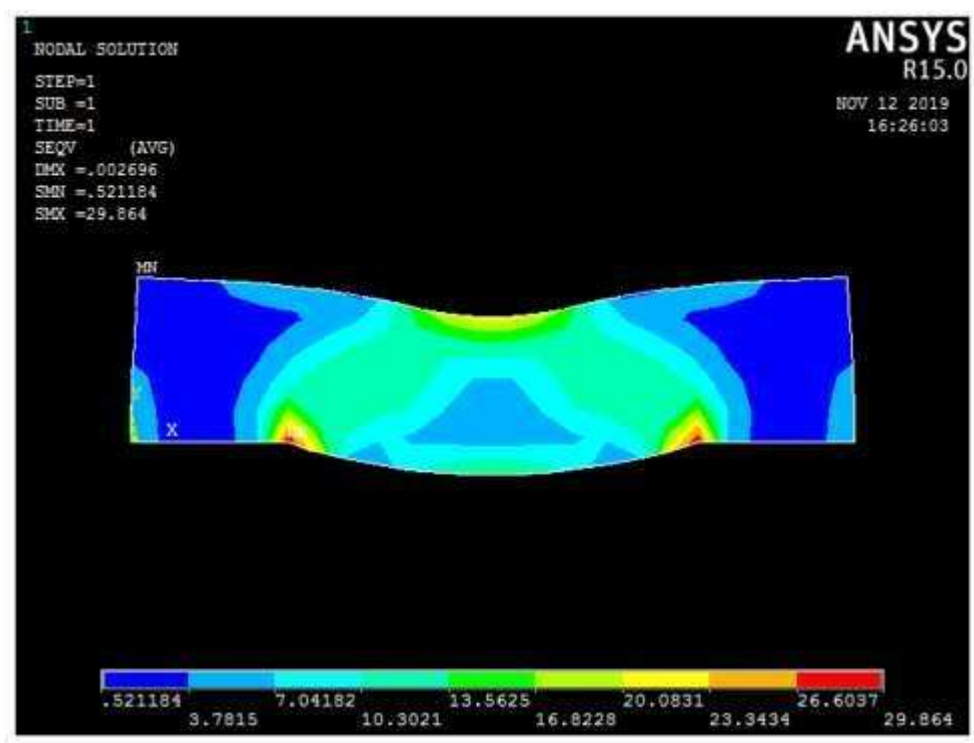

Gambar 3. Hasil simulasi tegangan pada pin 


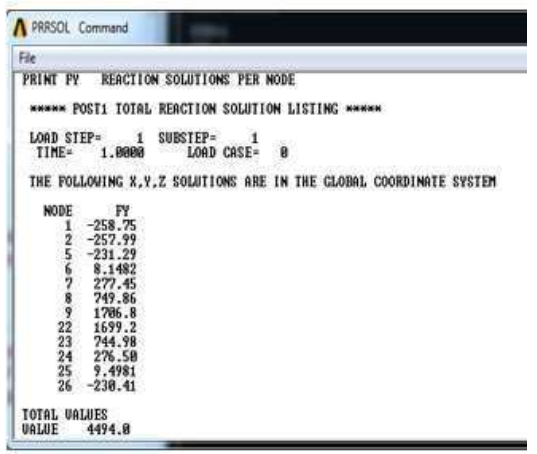

Gambar 4. Gaya reaksi pada masing-masing nodal pin yang kontak langsung dengan lifting lug
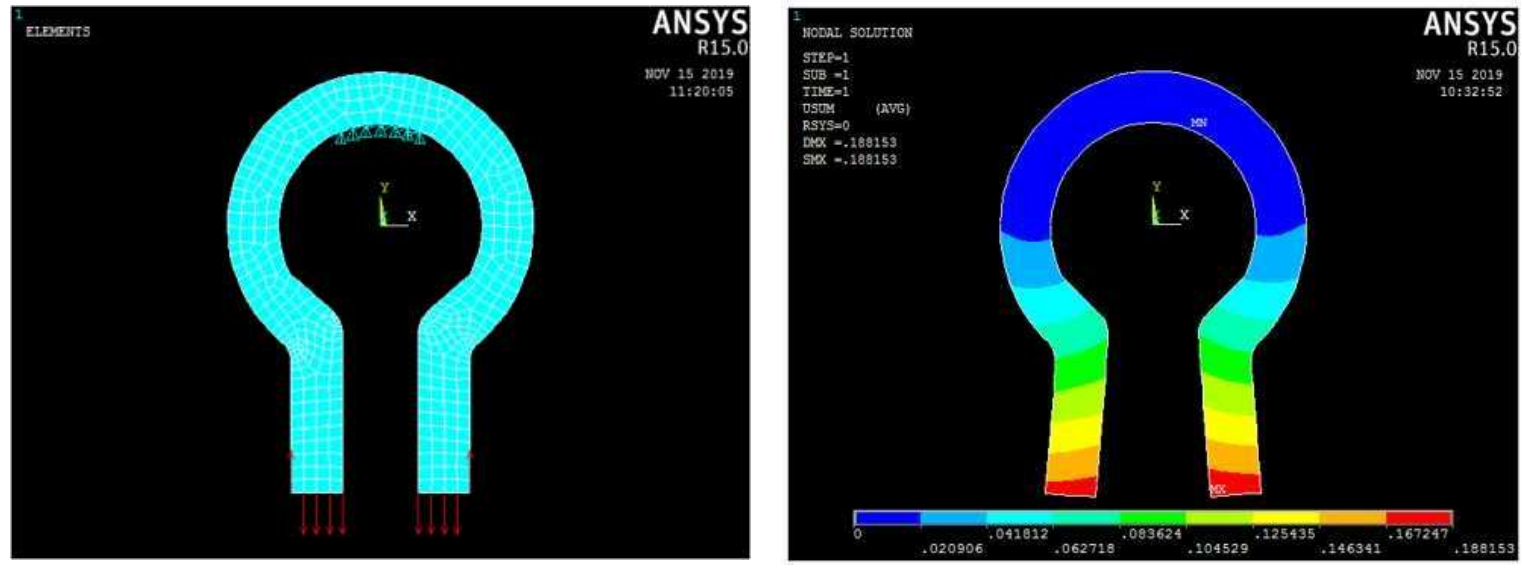

Gambar 5. Pemodelan dan pembebanan pada objek shackle
Gambar 6. Hasil simulasi perpindahan nodal pada shackle

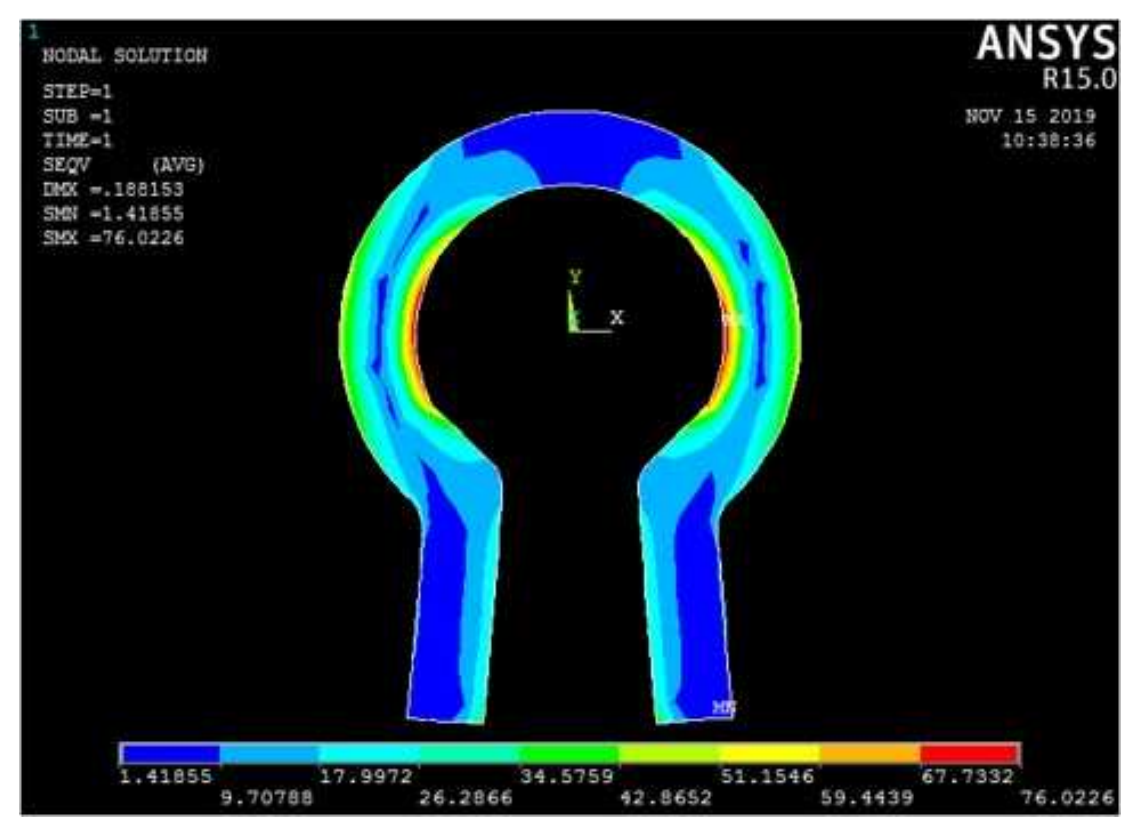

Gambar 7. Hasil simulasi distribusi tegangan pada shackle 
Harahap, A.A.M., Simulasi Pembebanan Pada Shackle Menggunakan ....

$$
\begin{aligned}
& \text { Berdasarkan hasil simulasi } \\
& \frac{\sigma_{1}-\sigma_{3}}{2} \geq \frac{s_{y}}{2} \\
& \frac{0,0000-(-33,962)}{2} \geq 145000 \mathrm{MPa}
\end{aligned}
$$

\section{$\frac{33,962 \mathrm{MPa}}{2} \geq 145000 \mathrm{MPa}$}

diperlihatkan bahwa perpindahan nodal maksimum terjadi pada kaki-kaki shackle karena beban awal dibangkitkan pada daerah tersebut. Hal ini diperjelas dengan tampilan grafik perpindahan nodal disepanjang permukaan shackle seperti diperlihatkan pada gambar 8 .

Tetapi nilai perpindahan yang terjad masih sangat kecil, dimana nilai maksimumnya hanya sebesar $0,18 \mathrm{~mm}$. Dengan demikian berdasarkan perpindahan nodal, konstruksi shackle masih aman untuk dipergunakan.

Kekuatan pin shackle dihitung dengan menggunakan teori kegagalan tegangan geser maksimum berdasarkan hasil simulasi. Dari hasil simulasi pada struktur shackle diketahui tegangan ekivalen terbesar terdapat pada Node 9 dengan : $\sigma 1=0,0000 \mathrm{MPa}, \sigma 2=-11,707$ $\mathrm{MPa}, \quad \sigma 3=-33,962 \mathrm{MPa}$. Kegagalan struktur akan terjadi apabila memenuhi kriteria pada persamaan (5). Besarnya ialah sebagai berikut:

\section{$16,981 \mathrm{MPa}<145000 \mathrm{MPa}$}

Berdasarkan simulasi tersebut, tegangan yang terjadi masih jauh lebih kecil dibandingkan dengan setengah dari kekuatan luluh bahan. Oleh karena itu, kontruksi shackle dapat dinyatakan aman berdasarkan teori kegagalan tegangan geser maksimum.

Dari hasil simulasi pada struktur shackle diketahui tegangan ekivalen terbesar terdapat pada Node 26 dengan : $\sigma 1=0,0000 \mathrm{MPa}, \sigma 2=-0,28574 \mathrm{MPa}, \sigma 3$ $=-0,96401 \mathrm{MPa}$. Kegagalan struktur akan terjadi apabila memenuhi kriteria pada persamaan (5).

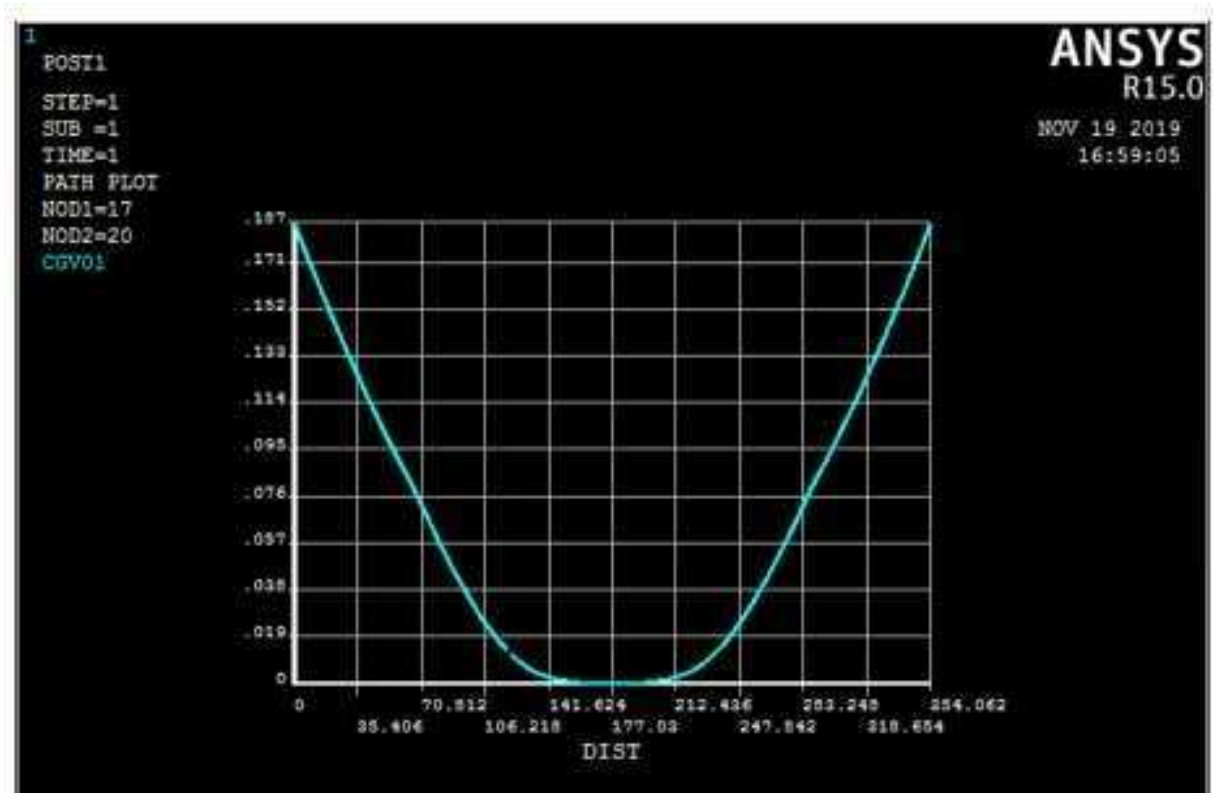




$$
\begin{aligned}
& \frac{\mathrm{a}_{1}-\mathrm{a}_{3}}{2} \geq \frac{\mathrm{Sy}}{2} \\
& \frac{0,0000-(-0,96401)}{2} \geq 145000 \mathrm{MPa}
\end{aligned}
$$$$
\text { Gambar 8. Grafik perpindahan nodal disepanjang permukaan shackle }
$$

\section{Ternyata :}

\section{$0,482005 \mathrm{MPa}<145000 \mathrm{Mpa}$}

Berdasarkan perhitungan tersebut di atas, tegangan yang ditimbulkan akibat beban eksternal jauh lebih kecil jika dibandingkan dengan setengah tegangan Yield nya. Oleh karena itu struktur shackle dinyatakan aman apabila diberi beban kerja sebagaimana yang telah dilakukan.

\section{KESIMPULAN}

Berat tangki ialah 916,72 kg dan skid pada tangki berjumlah 2,sehingga berat tangki dibagi 2 sehingga diperolah berat totalnya $458,36 \mathrm{~kg}$. Selanjutnya berat ini dikonversikan ke satuan gaya, sehingga diperoleh beban tangki yang akan digunakan untuk simulasi. Gaya yang terjadi pada tangki ialah sebesar 4491,92 N.

Hasil simulasi pembebanan pada tangki ialah: defleksi maksimum terjadi pada bagian tengah pin dengan nilai sebesar 0,002696 mm. Berdasarkan hasil simulasi ini menunjukkan bahwa defkelsi yang terjadi pada pin sangat kecil sehingga pin aman terhadap beban tersebut. Tegangan maksimum yang terjadi pada pin terdapat pada tengan batang. Besarnya tegangan ialah 29,86 MPa. Defleksi maksimum pada rangkah shackle yaitu sebesar 0,188153 mm.
Tegangan maksimum pada rangkah shackle yaitu sebesar 76.0226 MPa.

Berdasarkan perhitungan teori kegagalan Tegangan Geser Maksimum (Maximum Sheare Stress), tegangan yang ditimbulkan akibat beban eksternal jauh lebih kecil dari tegangan Yield-nya. Pada kedua struktur shackle tersebut, besarnya tegangan maksimum yang terjadi berdasarkan hasil simulasi masih jauh lebih kecil dari kekuatan luluh beban. Demikian juga berdasarkan perhitungan teori kegagalan Teori Energi Distorsi (Distortion Energy), tegangan maksimum yang terjadi akibat beban eksternal juga jauh lebih kecil dari tegangan Yield-nya. Dengan demikian struktur shackle dapat dinyatakan aman untuk digunakan pada beban kerja tersebut.

\section{PENGHARGAAN}

Ucapan terima kasih kepada Bapak Zulfikar, ST. MT. yang telah membimbing Saya dalam menyelesaikan penelitian ini dan juga Program Studi Teknik Mesin, Universitas Medan Area, Medan, yang telah memberikan fasilitas kepada peneliti sehingga penelitian dapat diselesaikan dengan baik.

\section{REFERENSI}

[1] Y. Dou and L. Yu, "Numerical investigations of the effects of different design angles on the motion behaviour of drag anchors," Applied Ocean Research, vol. 76, no. 1, pp. 199-210, 2018.

[2] J. D. Pauw, P. D. Baets, Y. P. Delgado, J. Sukumaran and W. Ost, "A full scale test rig for assessment of abrasive wear of shackle chains," Wear, vol. 302, no. 1, pp. 1017-1025, 2013. 
Harahap, A.A.M., Simulasi Pembebanan Pada Shackle Menggunakan ....

[3] A. J. Zulfikar, B. Umroh, A. Amrinsyah and F. A. Nasution, "Numerical Analysis of Strength of Rear Brake Holder Flat on The Motor," JMEMME (Journal Of Mechanical Engineering, Manufactures, Materials And, vol. 2, no. 1, pp. 1-6, 2018.

[4] A. Sofyan, J. Glusevic, A. J. Zulfikar and B. Umroh, "Analisis Kekuatan Struktur Rangka Mesin Pengering Bawang," JMEMME (Journal of Mechanical Engineering Manufactures Materials and Energy), vol. 3, no. 1, pp. 20-28, 2019.

[5] A. J. Zulfikar, A. Sofyan and M. Y. Siahaan, "Numerical Simulation on The Onion Dryer Frame Capacity of 5 $\mathrm{kg} /$ hour," JMEMME (Journal of Mechanical Engineering Manufactures Materials and Energy), vol. 2, no. 2, p. 86-92, 2018.

[6] D. Nainggolan, A. J. Zulfikar and B. Umroh, "Analisa Gaya Dan Sudut Rahang Pada Alat Pembuka Buah Durian Metode Gerak Putar Relatif," JMEMME (Journal of Mechanical Enggineering, Manufactures, Materials and Energy), vol. 3, no. 2, pp. 84-91, 2019.

[7] A. J. Zulfikar, B. Umroh and M. Y. Siahaan, "Design And Manufacture of Skateboard From Banana Stem," JMEMME (Journal of Mechanical Enggineering, Manufactures, Materials and Energy), vol. 3, no. 2, pp. 109-116, 2019.

[8] J. A. Shigley, Mechanical Engineering Design, New York: Mc Graw Hill, 2008.

[9] D. Darianto, B. Umroh, A. Amrinsyah and A. J. Zulfikar, "Numerical Simulation on Mechanical Strength of a Wooden Golf Stick," JMEMME (Journal Of Mechanical Engineering, Manufactures, Materials And Energy), vol. 2, no. 1, p. 13-19, 2018. 